\title{
Correction to: Inter-agency Collaboration for Graduate Employment Opportunities in Uganda: a Case for Investigating the Structure, Social Capital, and Agency of Organizations
}

\section{Peter Dithan Ntale ${ }^{1}$ (D) Jude Ssempebwa ${ }^{2} \cdot$ Badiru Musisi $^{2} \cdot$ Holly C. Pope $^{3}$}

Published online: 16 May 2019

(C) Springer Science+Business Media, LLC, part of Springer Nature 2019

\section{Correction to: Journal of African American Studies https://doi.org/10.1007/s12111-019-09419-9}

The original version of this article contained an error. Three authors were previously missing in the author byline.

The correct author list is shown above.

The original article has been corrected.

With reference to the above correction, the Acknowledgements section of the original version will now read:

Acknowledgments I acknowledge the contribution of Dr. Genza Gyaviira Musoke and Assoc. Prof. Ngoma Muhammed. They have been valuable resources in the development of this work.

Publisher's Note Springer Nature remains neutral with regard to jurisdictional claims in published maps and institutional affiliations.

The online version of the original article can be found at https://doi.org/10.1007/s12111-019-09419-9

Peter Dithan Ntale pntale@mubs.ac.ug

1 Makerere University Business School, PO Box 1337, Kampala, Uganda

2 College of Education and External Studies, Makerere University, PO Box 7062, Kampala, Uganda

3 Arnold School of Public Health, University of South Carolina, Columbia, SC, USA 